\title{
Use of CNG as Autofuel in Nigeria
}

\author{
Ubani E. Chikwendu and Ikpaisong S. Ubong
}

\begin{abstract}
Natural gas is a clean-burning, safe fuel that can save you money at the pump while benefitting the environment and reducing Nigeria's dependence on petroleum. It is a naturally occurring mixture of gaseous hydrocarbon, nongaseous non-hydrocarbons and gaseous non-hydrocarbons found in underground reservoir rocks either on its own (nonassociated gas) or in association with crude oil (associated gas). Natural gas is today accepted as one of the best sources of energy for the world and for the future because of its environmentally-friendly nature compared to other kinds of fossil fuels. Nigeria is ranked as the seventh most natural gas endowed nation in the world and relaxes on number one spot in Africa as she seats on about one hundred and eighty-eight trillion cubic feet of natural gas deposits.

Current opportunities to utilize gas in Nigeria include: Gas to reinjection schemes, Gas to power schemes, Gas to petrochemicals (as feedstock), LNG-Liquefied Natural Gas, LPG- Liquefied Petroleum Gas, and CNG- Compressed Natural Gas. The use of CNG as auto fuel in Nigeria presents so much benefits as have been highlighted in this paper with emphasis on the economic advantage. Compressed Natural Gas (CNG) is a product of compressing natural gas to one hundredth the volume it occupies at standard atmospheric pressure.
\end{abstract}

A comprehensive economic analysis to determine the cost savings from driving a car on CNG against PMS considered the case of a motorist who covers an average of $100 \mathrm{~km}$ every day in the approximately thirty days that make a month was employed. Results established that running a car on CNG amounts to saving N1 143 daily and N34 284 monthly, the cost of converting the car from PMS - driven to CNG - driven is recovered before the end of the sixth month. From the sixth month to the end of the first year, savings of $\mathrm{N} 211402$ is made. Savings of N411 408 is enjoyed each year after the first year.

Running vehicles on CNG will greatly reduce the friction and troubles encountered in importing fuel into the country. This will also cut down largely the hardly available foreign exchange expended in bringing in PMS for fuelling vehicles. To this end, the Nigerian Government should as a matter of national development ensure legal and regulatory framework encompassing both technical and commercial aspects for natural gas utilization in Nigeria. Worthy of note is the aspect of gas gathering, gas transmission and distribution which will further encourage the planting of CNG refuelling stations that will serve the expected large fleet of natural gas vehicles. Currently, Green Gas Limited, a joint venture between Nigeria Gas Company (NGC) a Nigerian National Petroleum Corporation (NNPC) and NIPCO Plc. that has nine operational CNG refuelling stations and others under construction is the only company driving the CNG revolution in the country.

Index Terms-Autofuel; Compressed Natural Gas (CNG); Naira.

Published on October 22, 2018.

U. E. Chikwendu is with the Department of Petroleum and Gas Engineering, University of Port Harcourt, Rivers State, Nigeria. (e-mail: chikwendu.ubani@uniport.edu.ng)

I. S. Ubong is with the Department of Petroleum and Gas Engineering, University of Port Harcourt, Rivers State, Nigeria. (e-mail: ubong.ikpaisong@uniport.edu.ng)

\section{INTRODUCTION}

Natural gas is a naturally occurring mixture of gaseous hydrocarbon, non-gaseous non-hydrocarbons and gaseous non-hydrocarbons found in underground reservoir rocks either on its own (non-associated gas) or in association with crude oil (associated gas). Natural gas is today accepted as one of the best sources of energy for the world and for the future because of its environmentally-friendly nature compared to other kinds of fossil fuels. Nigeria is ranked as the seventh most natural gas endowed nation in the world and relaxes on number one spot in Africa as she seats on about one hundred and eighty-eight trillion cubic feet of natural gas deposits [1].

Oil and gas experts believe that Nigeria would earn more from full utilization of gas resources than what it is currently been realized from crude oil exports [2]. Current opportunities to utilize gas in Nigeria include:

1. Gas to reinjection schemes

2. Gas to power schemes

3. Gas to petrochemicals (as feedstock) [3]

In the same vein, natural gas is also being utilized in these three different physical forms:

- $\quad$ LNG-Liquefied Natural Gas

- $\quad$ LPG- Liquefied Petroleum Gas

- $\quad$ CNG- Compressed Natural Gas

Owing to the drawback in the collection and transportation/storage often associated with natural gas, it is usually shipped in liquid form from an available region to where it is needed. Natural gas in this form is referred to Liquefied Natural Gas (LNG). LNG occupies 1:600 of its original volume, helping to reduce transportation costs considerably. Nevertheless, the special treatments required during liquefaction and transport means LNG attracts huge CAPEX. Natural gas is also compressed to 200 bar to achieve a $99 \%$ volume reduction, and hence make it more portable. Natural gas stored in this form is known as CNG. Although CAPEX for CNG production is considerably lower than that of LNG, there is an element of risk because it is stored in a pressurized cylinder. The last form is Liquefied Petroleum Gas. LPG is usually produced during crude oil refining. LPG composition is mainly propane and butane. Its high calorific and heating values have made it the most popular household cooking gas in most of the third world countries

Of all these fractions, Nigeria currently exports 18.6 million tonnes per annum of LNG [4] while LPG usage among the populace for domestic cooking is on the rise. Several merits exist for boosting these figures and also increasing the use of other natural gas fractions. For example, the nation could have been immune from the plummeting GDP from the current low price regime in crude oil sales if avenues for the utilization of LPG are explored as 
an alternative to kerosene for household cooking. Furthermore, in Nigeria, the volatility in PMS market is often felt more in the auto industry and has been the cause of several face-offs between the government and organized labor. This can be curtailed if alternatives like Compressed Natural Gas (CNG) are explored. It is against this backdrop that we attempt to throw light on the benefits of CNG to the Nigerian auto industry.

\section{AUTOMOBILES AND CNG UTILIZATION}

Natural gas has used as fuel been in domestic households for many years but it has not achieved mainstream use as fuel for automobiles. Today $\mathrm{CNG}$ is gradually being recognized as one of the most viable alternative fuel options available. Being a much cleaner fuel source, its increased portability and reduced cost has made it very popular as a transportation fuel. Presently, there is an increasing use of $\mathrm{CNG}$ in public transportation. For example, cities like New Delhi have made CNG usage in public transportation very mandatory, resulting in considerable pollution reduction. In the past, owing to its heavy and voluminous tank requirement, CNG deployment in small vehicles was not widespread. However, this has considerably advanced over the last decade by the development of lightweight highpressure storage cylinders. [5].

Compressed Natural Gas (CNG) is a product of compressing natural gas to one hundredth the volume it occupies at standard atmospheric pressure. It is contained and distributed in hard cylindrical or spherical containers at pressures between 3000 to 3600 psi. It is mostly used for generating power and as fuel for vehicles. Natural Gas Vehicles (NGVs) drive on CNG stored in cylinders installed in the rear, roof or undercarriage of the vehicles. When needed to power the vehicle the natural gas leaves the cylinder to the engine combustion chamber through a specially designed system. [6].

\section{DRIVERS OF CNG UTILIZATION IN AUTOMOBILES}

This study highlights the advantages of Natural Gas Vehicle (NGV) technology for natural gas utilization especially the economics of running a vehicle using natural gas compared to running same vehicle on the conventional premium motor spirit. In section we shall briefly review some of the key drivers of CNG utilization in the auto industry.

\section{A. Environmental Factor}

$\mathrm{CNG}$ is eco-friendlier than gasoline. Natural gas produces far fewer harmful emissions and hydrocarbons than gasoline. Using CNG makes the engine cleaner and more efficient. Unlike gasoline, CNG minimizes harmful carbon deposits when combusted. This results to a cleaner and more efficient engine as well as longer lasting spark plugs. In addition, oil changes are also minimized because of carbon deposits that contaminate the oil is eliminated.

Another commonly cited major positive aspect of CNG use is that being a natural gas (methane content) its exhaust emissions contains just water vapour and minuscule quantity of carbon monoxide, no carbon or other particles. Being virtually pollution free $\mathrm{CNG}$ driven vehicles meet the most stringent of emission standards worldwide.

\section{B. Efficiency of the Vehicle}

Several other factors contribute to the growing use of CNG such as its higher ignition temperature is higher compared to petrol. Secondly, $\mathrm{CNG}$ has a narrow combustion range when compared to petrol. The octane rating of natural gas is about 130 meaning that engines could operate at compression ratio of up to $16: 1$ without "knock" or detonation. [7].

\section{Safety \& Environment}

Natural gas is lighter than air and will disperse into the atmosphere if it leaks from its storage vessel - having a negative impact on greenhouse gas (GHG) emissions, but a positive impact on fuel safety. Diesel and other liquid fuels may leak and form pools, which is an environmental and safety concern. Overall, natural gas is less hazardous than diesel fuel.

\section{Low Operation and Maintenance Costs}

CNG vehicles are normally gasoline vehicles with added components to store and feed CNG to the engine. Long-term maintenance costs can actually be lower, due to the fact that $\mathrm{CNG}$ is a cleaner-burning fuel and generates less wear-andtear on some engine components. In addition, due to the absence of additives like lead and benzene in CNG, lead fouling of spark plugs is reduced to barest minimum. There is an increase in the life of lubricating oils, as CNG does not contaminate and dilute the crankcase oil [6]. This is mainly because it enters the engine as gas while petrol comes in as spray or mist which washes down the lubricating oil from the piston ring area to raise the rate of engine depreciation. This reduces maintenance costs and engine life goes.

\section{ECONOMIC ANALYSES AND LIFECYCLE COST ANALYSES}

In this section, we will review the economic advantages of running a vehicle using natural gas compared to running same vehicle on the conventional premium motor spirit. A comparative economic analysis was carried out on the capital expenditure and operating expenditure of running a vehicle on $\mathrm{CNG}$ against running same vehicle on the conventional gasoline (premium motor spirit - PMS) for a given distance.

Factors considered in making the comparison include initial cost of converting the vehicle from a PMS - driven vehicle to a CNG - driven vehicle. The capital cost of the vehicle is not considered as it is same vehicle. Other economic factors considered is a conversion cost of about $\mathrm{N}$ 200000 required to convert a conventional automobile to CNG [8]. Tables 1 and 2 are used to estimate the fuel consumption of a car driven on PMS and one driven on CNG. 
TABLE I: RUNNING COST OF CAR PER KILOMETER TRAVELLED IN $2011^{1}$

\begin{tabular}{lll}
\hline \hline \multirow{2}{*}{ Vehicle type } & \multicolumn{2}{l}{ Running Cost } \\
& Petrol & CNG \\
\hline Car & N14/Km & N5.5/Km \\
\hline \hline
\end{tabular}

TABLE II: PRICE OF VEHICLE FUELS IN $2011^{2}$

\begin{tabular}{ll}
\hline \hline Fuel & Cost (Naira) \\
\hline Petrol & $97 /$ litres \\
CNG & $55 / \mathrm{SCM}$ \\
\hline \hline
\end{tabular}

From tables I and II above, it is established that the fuel consumption is 0.14432 litre for each $\mathrm{km}$ travelled for a car running on PMS and 0.1 standard cubic metre per $\mathrm{km}$ for a CNG - driven car. Refer Table III. This information is further used in determining the cost savings made driving a vehicle on PMS versus CNG.

TABLE III: FUEL CONSUMPTION PER KILOMETRE

\begin{tabular}{ll}
\hline \hline Fuel consumption & \\
\hline Petrol (litre/km) & CNG $(\mathrm{SCM} / \mathrm{km})$ \\
0.14432 & 0.1000 \\
\hline \hline
\end{tabular}

\section{For a distance of $100 \mathrm{~km}$}

To carry out a comprehensive economic analysis to determine the cost savings driving a car on CNG over PMS, the case of a motorist who covers an average of $100 \mathrm{~km}$ every day in the approximately thirty days that make a month is employed. [9]. The analysis involved the use of fuel consumption for the car (Table III above) and the current prices of vehicle fuels in Nigeria. (See Table IV)

\begin{tabular}{ll}
\multicolumn{2}{l}{ TABLE IV: CURRENT PRICES OF VEHICLE FUELS IN NIGERIA } \\
\hline \hline Fuel & Cost (Naira) \\
\hline Gasoline (PMS) & $145 /$ litre \\
Diesel (AGO) & 160/litre \\
CNG & $95 / \mathrm{SCM}$ \\
\hline \hline
\end{tabular}

Cash flow is generated for a car that runs on CNG on a monthly basis, refer Table VI.

Monthly savings $=$ Daily savings $* 30=N 1142.783505 * 30=$ N34 283.50515

\begin{tabular}{|c|c|c|c|c|c|}
\hline $\begin{array}{l}\text { Fuel } \\
\text { consumpti } \\
\text { on }\end{array}$ & $\begin{array}{l}\text { Distan } \\
\text { ce } \\
\text { in a } \\
\text { day } \\
(\mathrm{km})\end{array}$ & $\begin{array}{l}\text { Total } \\
\text { fuel } \\
\text { consump } \\
\text { tion/day }\end{array}$ & $\begin{array}{l}\text { Fuel } \\
\text { cost } \\
\text { (Nair } \\
\text { a) }\end{array}$ & $\begin{array}{l}\text { Total } \\
\text { Fuel } \\
\text { cost/day } \\
\text { (Naira) }\end{array}$ & $\begin{array}{l}\text { Daily } \\
\text { Savings on } \\
\text { CNG over } \\
\text { petrol } \\
\text { (Naira) }\end{array}$ \\
\hline $\begin{array}{l}0.14432 \\
\text { litre } / \mathrm{km}\end{array}$ & 100 & $\begin{array}{l}14.432 \\
\text { litre }\end{array}$ & $\begin{array}{l}\text { 145/ } \\
\text { litre }\end{array}$ & 2092.78 & 1142.78 \\
\hline $\begin{array}{l}0.1 \\
\mathrm{SCM} / \mathrm{km}\end{array}$ & 100 & $10 \mathrm{SCM}$ & $\begin{array}{l}95 / \mathrm{S} \\
\mathrm{CM}\end{array}$ & 950 & \\
\hline
\end{tabular}

Payback period $=\frac{\text { Initial outlay }}{\text { Annual cash flow }}=\frac{200000}{34283.50515}=5.8337$ months
TABLE VI: ANNUAL CASH FLOW

\begin{tabular}{lll}
\hline \hline Month & Cash Flow & Cumulative Cash Flow \\
\hline 0 & $(200000)$ & \\
1 & 34283.50515 & $(165716.4949)$ \\
2 & 34283.50515 & $(131432.9897)$ \\
3 & 34283.50515 & $(97149.48455)$ \\
4 & 34283.50515 & $(62865.9794)$ \\
5 & 34283.50515 & $(28582.47425)$ \\
6 & 34283.50515 & 5701.0309 \\
7 & 34283.50515 & 39984.53605 \\
8 & 34283.50515 & 74268.0412 \\
9 & 34283.50515 & 108551.5464 \\
10 & 34283.50515 & 142835.0515 \\
11 & 34283.50515 & 177118.5567 \\
12 & 34283.50515 & 211402.0618 \\
\hline \hline
\end{tabular}

\section{SUMMARY OF RESUlTS}

Daily saving on CNG over PMS = N1 143

Monthly saving = 34284

Payback period $=$ approximately 6 months

\section{CONCLUSION AND RECOMMENDATION}

From the economic analysis and results above, running a car on CNG over PMS amounts to a daily savings of N1 143 and N34 284 monthly, and the cost of converting the car to CNG driven car is recovered before the end of the sixth month. From the sixth month to the end of the first year, savings of N211 402 is made. For subsequent years, savings of N411 408 is enjoyed each year. Apart from the economic advantage, other benefits highlighted above such as environmentally friendly, vehicle performance and efficiency, safety and low operation and maintenance cost make it a choice fuel for vehicles in Nigeria. The abundance of Nigeria's natural gas reserves in excess of 187 trillion cubic feet further establishes its necessity to be the fuel to drive vehicles in the country.

Running vehicles on CNG will greatly reduce the friction and troubles encountered in importing fuel into the country including subsidy payment and the accompanying disagreements. This will also cut down largely the hardly available foreign exchange expended in bringing in PMS for fuelling.

The Nigerian Government should as a matter of national development ensure legal and regulatory framework encompassing both technical and commercial aspects for natural gas utilization in Nigeria. Worthy of note is the aspect of gas gathering and gas transmission/distribution which will further encourage the planting of CNG refuelling stations that will serve the expected large fleet of natural gas vehicles. Currently, Green Gas Limited, a joint venture between Nigeria Gas Company (NGC) a Nigerian National Petroleum Corporation (NNPC) and NIPCO Plc. that has nine operational $\mathrm{CNG}$ refuelling stations and others under construction is the only company driving the $\mathrm{CNG}$ revolution in the country [10].

\footnotetext{
${ }^{1}$ Source: Green Gas Limited, 2011.

${ }^{2}$ Source: Nigerian National Petroleum Company, 2011
} 


\section{REFERENCES}

[1] BP Statistical. BP Statistical Review of World Energy. s.1. : BP, 2016.

[2] Monday, Umoh Victor. The role of gas engineer in actualizing vision 2020. Port Hacourt : s.n., 2011.

[3] NGA. NGA Study Group 3 Report on Domestic, Commercial and Transportation in the Nigerian Gas Industry. s.1.: Nigerian Gas Association, 2016.

[4] IGU. 2017 World LNG Report. s.1. : International Gas Union, 2017.

[5] Rosi, Semin. Technical Review of Compressed Natural Gas as an Alternative Fuel for Internal Combustion Engines. s.1. : Automotive Excellent Center, Faculty of Mechanical Engineering .

[6] NIPCO, PLC. NIPCO FAQs. NIPCO. [Online] [Cited: 1212 2017.]
[7] CNG-ONE. CNG-ONE, LLc. CNG-ONE website. [Online] [Cited: 10 February 2018.] www.cng-one/info/beenefits.asp.

[8] Aderibigbe, Adeyinka. Embracing Natural Gas as Fuel. s.1.: The Nation, 2017.

[9] A Review on Natural Gas Utilization and Cutting Carbon Emissions: How viable is Compressed Natural Gas for Road Vehicle Fuels? Chikezie, Nwaoha and Udoka, Jeremiah I. 2013, Journal of Energy Technologies \& Policy.

[10] Energy Mix, Report. Energy Mix Report: Alternative \& Renewable Energy . Energy Mix Report website. [Online] 4 march 2014. [Cited: 10 february 2018.] energymixreport/whynigerianvehicles should run on natural gas. 